\title{
Rhethorics and Realities of Managing Ethno-Religious Conflicts: the Nigerian Experience
}

\author{
Beloveth Odochi Nwankwo* \\ University of Derby, Kedleston Old Road, College of Law, Humanities and Social Sciences, Derby, United Kingdom \\ *Corresponding author: belovethodo@yahoo.com
}

Received February 26, 2015; Revised February 28, 2015; Accepted March 01, 2015

\begin{abstract}
Political, ethno-religious or social conflicts often spring from the pursuance of divergent ideas, aspirations and interests expressed by a group of people or individuals under particular environmental conditions. Nigeria, like many African countries, is a multi-ethnic country with over 250 ethnic groups, where Islam and Christianity are the two predominant religious beliefs. Since independence, in 1960, Nigeria has struggled to control ethno-religious conflicts. Currently, these conflicts are on the increase with the formation of various ethno-religious militias, such as the Oodua People's Congress (OPC), the Bakassi Boys, the Egbesu Boys and most recently Boko Haram. These conflicts manifest themselves in the form of riots, sabotage, assassination, armed struggles, guerrilla warfare and campaigns for secession. This article explores the rhetoric and realities of managing ethno-religious conflicts in Nigeria with an emphasis on the nature of the conflicts, the protagonists and the management mechanisms employed in that country. In terms of methodology, this study was designed to survey primary and secondary sources of literature relevant to the study. It is a case study analysis of ethno-religious issues in the country. In essence, it has contextualised the study based on religion and ethnic considerations. The sources of data include a survey of the Nigeria Watch database which maps the trends of violent deaths in Nigeria, articles on religious and ethnic violence; newspapers; and, pertinent books, alongside content analysis of the qualitative data. The article argues that one of the abatement measures is that every group must discourage the primordial sentiments in communities expressed by ethnic and religious groups.
\end{abstract}

Keywords: conflict, colonialism, ethnicity, religion, faith and nigeria

Cite This Article: Beloveth Odochi Nwankwo, "Rhethorics and Realities of Managing Ethno-Religious Conflicts: the Nigerian Experience.” American Journal of Educational Research, vol. 3, no. 3 (2015): 292-300. doi: 10.12691/education-3-3-7.

\section{Introduction}

\subsection{Description of the Study}

This study examines the rhetoric and realities of managing ethno-religious conflicts in Nigeria. Nigeria is a multi-ethnic country that provides a perfect country-case study for ethno-religious conflict (Salawu, 2010; Olojo, 2014, Danjibo, 2012). It has over 250 ethnic nationalities that on the whole are either Christian or Muslim. Notwithstanding, the level of religious devotion has made Nigeria a conflict ridden country. Historically, religious extremists have tried to legalise violent behaviour and bloodshed in the name of God. This is apparent in the violent terrorist attacks that are justified by people who believe that they are involved in a form of holy warfare. In this context, Juergensmeyer's concept of “cosmic war" (Juergensmeyer, 2000) provides a useful theoretical structure for investigating the conflict that religious extremists indulge in today. This framework refers to the encounter between the forces of evil and good that highlights religious humility, yet induces conflict. Killing in the name of God is therefore one of the major motors of religious violence today (Juergensmeyer, 2000, p. 6).

According to Salawu (2010), in the last two decades, religion has been at the heart of most violent conflicts in the world. This may be the reason why religion has been referred to as one of the key security challenges facing humanity since after the end of the Cold War (Barnard, 2011). However, even though this study agrees that religion is one of the key challenges of human security, it does not accept that the security challenges posed by religion can only be seen in the past two decades. By contrast, this author premises that religion has been a major issue triggering conflict since the $14^{\text {th }}$ century if not earlier. For example, most studies show that in the late Middle Ages from the start of the Reconquista in 718 until the fall of Grenada in 1492, the presence of religious differences in Spain had resulted in more concentrated religious but not political conflicts. (Ikelegbe, 2001) This resonates with the Nigerian experience and the position occupied by violent religious conflicts and insecurity in Nigerian society.

\subsection{Religious Motivations for 9/11(United States)}


The clash of civilisation between the West and the Arab world greatly inspired the September 112001 terrorist attacks in the USA, the 2002 terrorist attacks in Madrid, and the 2005 attacks in London, all indicating that religion is no longer just the opium of the masses because it has become a factor that determines the ideologies of states (Danjibo, 2012, p. 231). In essence, religious ideological differences also motivate an increase in violence based on religious differences. The attack on World Trade Centre on September 112001 marked a new dimension in religious violence across the world. The situation created fear, an atmosphere of insecurity and psychological trauma for both the families of victims and policymakers in other countries. This triggered Nigeria Watch into writing that "in the context of the global war on terrorism since 2001, religious conflicts are a very sensitive issue, especially when Muslim and Christian communities are involved" (2011, p. 21). Kible (2002) asserts that the religious motivation for the 9/11 attack (in the United States) was based on religious tensions as well as the instructions given to the attackers, which reads:

You should pray, you should fast ... you should ask God for guidance, you should ask God for help.... Continue to recite the [Koran]. Purify your heart and clean it from all earthly matters. The time of fun and waste has gone. The time of judgment has arrived ... You will be entering paradise. You will be entering the happiest life, everlasting life. On the fifth and the last page, guidance was given about how to enter the plane. The hijackers were asked to pray, oh Allah, open all doors for me. Oh Allah who answers prayers and answers those who ask you, I am asking for your help. I trust in you. I lay myself in your hands .... There's no God but Allah. I being a sinner. We are of Allah and to Allah we return (Kible, 2002, p. 1).

This instruction, no doubt, highlights the belief of both the writer of the instructions and the hijackers themselves who saw that their suicide mission was a religious one. The reasons for the attack on the United States World Trade Centre and the Pentagon are linked to the fact that Osama bin Laden viewed America as an enemy of Islam (Kibble, 2002). For that reason, he issued two fatwas- a decree issued by an Islamic leader - against America. Bin Laden's fatwas against America were declarations of Jihad or holy war based on the following issues:

1) In 1996, American troops entered into Saudi Arabia, the birth place of Mohamed and the Islamic Holy land (in this land non-members of Islam are seen as infidels).

2) In 1998, Bin Laden decreed for all Americans to be killed. He saw the American interest in Saudi Arabia as a selfish one given that America supported Israel against Islamic countries (Kibble, 2002). (These issues marked the beginning of the plot to bomb America).

\subsection{Sudanese-ethno-conflict}

Religion is said to be a pivotal factor in conflicts in multi-ethnic and religious societies such as Sudan and Nigeria. Observations show that violence is intricately linked with religion in Sudan and other countries in Africa where a strong religious ring is associated with ethnicity and nationalism (Danjibo, 2012, p. 235). Ethnic related violence has also contributed to the death of innocent citizens. In fact, in Sudan, ethno-centrism and ethnonationalism were responsible for the protracted sociopolitical armed conflicts that lingered until South Sudan gained its independence in 2011. Northern Sudan which makes up for roughly two-thirds of the land and population of Sudan is Muslim and Arab-speaking. This Northern identity is based on an inseparable amalgamation of Islam and the Arabic language. The Southern Sudanese is more of an indigenous African in race, culture, and religion because their identity is indigenously African, with Christian influences and a Western orientation (Barnard, 2011).

Although Christianity predated Islam in northern Sudan, it was effectively eradicated and replaced by Islam by the early sixteenth century (Barnard, 2011). It was then reintroduced to the southern part of the country through missionary work that was associated with British colonialism. Since independence in 2011, the South has been threatened by the policies of Arabization and Islamization (Barnard, 2011). Paradoxically, the religious persecution of non-Muslims is seen as advertising Christianity; Southerners now perceive Christianity as the most effective means of counteracting the imposition of Islam, especially as traditional religions cannot withstand the forces of spiritual and religious globalization (Kibble, 2002).

\subsection{The Clash of Religion}

The clash of religion is usually between Christianity and Islam. Christians and Muslims allow religious identity to generate avoidable conflicts which tolerance could have contained. The foregoing led Danjibo (2012, p. 234) to assert that modernization theory has not succeeded in sending religion to the grave.

In the Clash of Civilizations, Huntington (2003) argues that conflicts emanate from a world of divergent cultures since the end of the Cold War. In Huntington's (2003) argument, these cultures include Confucian, Western, Japanese, Muslim, Slavic-orthodox, Hindu, Latin America and possibly African civilizations. The 'clash of civilization's concept is of the view that Western cultural values and concepts differ significantly from other civilizations of the world. These differences are profound in the areas of free markets, liberalism, equality, constitutionalism, human rights, democracy, and the separation of religion from the state, among others. Tibi (1994) on the contrary argues that conflicts emanate from the divergent claims of Christian and Islamic civilisations. In other words, controversial universalism hinders a peaceful co-existence between Islam and Christian faith.

In Christian universalism, it is believed that there is one God Almighty and his son Jesus Christ who came to the world to redeem mankind. This son normally stands as a mediator between Christians and God. While Jesus was on the earth, he commissioned Christians to "go and make disciples of all the nations, baptising them in the name of the Father and of the Son and of the Holy Spirit" (Kibble, 2002). However, secularism- an approach which is indifferent to religion started in the $19^{\text {th }}$ century has not only dominated but replaced Christianity in the Western world by presenting such concepts as universalism, 
democracy, free markets and human rights in place of the Christian gospel (Good News) (Bodansky, 1999).

Similarly, in Islam, universalism is built on the concept of one God (Allah) and Mohamed the prophet. Muslim fanatics believe that the world is sub-divided into two: the house of Islam and the house of war (Kibble, 2002). These fanatics tend to be determined to convert the entire world into the house of Allah, hence, the belief that Western concepts such as democracy should be rejected and replaced with Islamic principles of governance such as Sharia, which they believe to be the most suitable political system. Fundamentalist Muslims share the belief that Islam will conquer the world and replace the existing political ideologies in the Western world thereby bringing salvation to the entire world (Taheri, 1987).

The fanatic Muslims appear to be misinterpreting the Koran, the Muslims' holy book that contains messages from Mohammed delivered the through angel Gabriel (Kibble, 2002). Some sects have misinterpreted some verses of the Koran, which portrays that there should be war until Islam controls the world. For example, the Koran (8; 38-39) says "Fight the unbelievers until there is no more tumult or oppression, and there prevail justice and faith in God altogether and everywhere. Fight those who believe not in God ... nor acknowledge the religion of truth, even if they are of the people of the book". This would normally imply a missionary battle rather than physical warfare.

However, the Muslim fundamentalist interprets these verses as a jihad and carries on a physical warfare with the rest of the world. Unfortunately, some fellow Muslims are also killed in the terrorist attacks. Kible (2002) believes that the clash between Islam and the West is perceived to be threatening because it is seen as being triggered by Western hegemonic forces based on technology and missiles.

\subsection{Methodology}

This study was designed to survey primary and secondary sources of literature relevant to the title. The materials for this study were derived from classical and recent case studies as well as the research and analysis of scholars, analysts and practitioners. This means that the primary method of study was an extensive survey of relevant secondary data for an in-depth analysis of issues surrounding ethno-religious conflicts in Nigeria. The major source of primary information is Nigeria Watch which provided the author with authentic statistical data with regards to the impacts of ethno-religious conflicts in Nigeria. Furthermore, the author reviewed the classical theories of Cosmic War and social identity on the one hand and on the other hand Samuel Huntington's modernist clash of civilization to ascertain the dimensions of the identity conflicts in Nigeria. The literature was carefully evaluated and analysed to determine its authenticity. In essence, this case study analysis contextualised the study based on religion and ethnic considerations.

\section{Literature Review}

\subsection{Ethnicity and History in Nigeria}

Historically, ethnicity is as old as the Nigerian state which gained independence in 1960. Ethnicity has different definitions. Every scholar defines the construct from his or her own point of view. However, most of the definitions accept the fact that ethnicity is an identity (Porter, 2011). Accordingly, an ethnic group is a group of people whose members identify with each other through a common language, culture, religion, ideology or geographical area (Porter, 2011). It is pertinent to note that ethnicity is difficult to define in the context of Africa, including Nigeria, because many scholars have viewed it from different perspectives. Ethnicity as a concept has come from the Greek word ethnos formerly posited on the foundation of national and cultural identity (Shepard, 1981, p. 209). Horton and Hunt (1980) have defined ethnic groups from a sociological point of view as a type of group that is socially identifiable as possessing its own separate sub-culture.

Historically, issues of ethnicity in Nigeria can be traced back to the colonial mistakes that forced the different ethnic groups of Northern and Southern provinces into becoming an entity called Nigeria in 1914 (Salawu, 2010). In 1947, it was split into three main political and ethnic groups: the North, made up of Hausa-Fulani, the West, made up of the Yoruba and the East made up of the Igbos among others. These groups, with diverse religious beliefs, represented 30, 20, and 18 percent of the Nigerian population respectively (Irobi, May 2005; Porter, July 25, 2011). These figures created by the British colonial administration changed over time. They are currently composed of various smaller ethnic groups which are under debate while the country is moving forward (Dike, 2006).

The result of British action in the process of nation building has been ethnic and religious conflict. It is possible that both the British administration and the Nigerian elites at the time could tell that Nigeria could not stand the test of time in unity. This is the reason why in the 1960s late Chief Obafemi Awolowo succinctly noted that Nigeria was a mere geographical expression- an assertion used in describing Italy by Prince Metternich a towering figure in Europe diplomacy in 1847 (London Evening Standard, Tuesday, May 13, 2014). Nigeria has experienced five successful coups, two abortive coups, one attempted coup and three alleged coups. ${ }^{1}$ The first and second coups were based on ethnic lines which culminated in the Biafra war (The Nigerian civil war 1967-1970), as the incompatible ethnic groups amalgamated by the then colonial administration opted for separatism. In other words, the seed of discord, division and ethnic nationalism in Nigeria is rooted in the legacies of colonialism. The recent Boko Haram onslaught on society as well as the kidnapping of over 200 Nigerian girls appears to have united Nigerians in the pursuance of

\footnotetext{
${ }^{1}$ The January 151966 coup led by Chukwuma Kaduna Nzeogwu, the 29 July 1966 coup led by Lieutenant Colonel Murtala Mohammad; the July 1975 coup led by General Yakubu Gowon; the 13th February 1976 failed coup led by Lieutenant-colenel Bukur Suka Dimka; the 1983 coup led by General Buhari Muhammadu; the 27 August 1985 led by General Ibrahim Babangida, the 1986 abortive coup led by Major-General Mamman Vatsa, the 22 April 1990 abortive coup led by Gideon Orka; the 2nd October 1993 attempted coup led by lieutenant-colonel Abubakar Umar; the 17th November 1993 coup led by Chief Ernest Shonekan and, the December 1996 alleged coup led by General Sunny Abacha.
} 
a common goal, witness the "bring back our girls" campaign (London Evening Standard, Tuesday 13 May, 2014). According to the list of names of the kidnapped girls, they appear to belong to nearly all the Nigerian ethnic and religious groups; hence, the unified effort in the country in the search for the girls.

The existence of strong tribal, ethnic and religious ties, which causes the Nigerian people alienation from the central administrative powers, undermines the rhetoric about peace by government and religious groups. This is because despite attempts in religious and governmental groups' attempts to bring about peace in Nigeria, the local people's affection for their religion and ethnic groups displaces any love for central government. This type of ethnic and religious composition in Nigeria appears to be making the development of a national identity almost impossible. It can also be argued that it accounts for the underdevelopment of society (Salawu, 2010).

Building a national identity is a daunting task in Nigeria. The three major ethnic groups -Hausa, Yoruba and Igboand the numerous minority ethnic groups owe their allegiances to their tribes and faiths. These large and divergent cultures as well as an unimaginable sense of tribal cohesion (Salawu, 2010) make it impossible for Nigeria to claim a unified nationality. The effort to achieve national unity has often triggered social discord and conflict within the country. The reason being that the ethnic groups in society often have the feeling, or belief, that they are being dominated by other more powerful groups. The level of mistrust and fear of dominance that is inherent in the ethnic groups drives them to believe that they do not believe that they get proper representation at a national level or that they get a fair share of the national cake (Albert, 1999). For instance, many Southerners maintain that the British colonial administration disadvantaged the Southern province in favour of the Northern Province (Salawu, 2010).

Furthermore, the tradition of maintaining the notion of referring to some members of the communities as settlers or aliens and others as natives, more often than not, triggers intra-ethnic conflict. The 'so-called' settlers, notwithstanding how long they have been in a community, are continually treated as strangers. For example, they do not possess the complete ownership of land, social position nor have a say in society unlike the natives of the communities. This often leads to the feeling of domination and marginalization within the communities (Abert, 1999).This has created a situation where the Nigerian Constitution provides for an underpinning that hinders national unity, the integration of citizens, and a sense of belonging among citizens. The aliens are not only discriminated against in terms of land ownership but are also mandated to pay extra taxes and are not allowed to settle in particular areas of the community (Salawu, 2010).

The major conflicts in Nigeria are based on either religious or ethnic cleavages. Usually, both lines are connected in terms of conflict manifestation hence; each ethnic region has its own designated religion. For instance, the Southern and Eastern parts of Nigeria are usually made up of Christians whereas the Northerners are mostly Muslims. This division complicates the political and social struggle in Nigeria as one particular ethnic group belongs to one religion and another to the other. This intensifies the division in the country thereby consolidating the different interests of the diverse tribes (Omotosho, 2003).

The Biafran war is a typical example of this. The conflict started with a political undertone but quickly transformed itself into a religious conflict. This war emanated from a political coup d'état and counter coup which took place in 1966. The Biafran war started with the secession of the Biafran state basically because of political grievance (Dike, 2003). Nevertheless, the Nigerian central government endeavoured to recuperate its control over the Biafran nation but the conflict was quickly transformed into both religious and ethnic conflicts between the Christian Southeast and the Muslim North. Notwithstanding, while the Biafran war ended a long time ago, the Igbo ethnic nationality in Eastern Nigeria is still of the perception that their ethnic group is being discriminated against (Dike, 2006).

\subsection{Religion in Nigeria}

Religion manifests itself in the relationship between human beings and God or anything they consider as sacred, which promotes supernatural beliefs (Danjibo, 2012, p. 232). Over time, religion has been defined in different ways. Some scholars argue that religion is a systematized structure of beliefs, observances, traditions, and worship that centre on one Supreme God, or Deity (Omotosho, 2003; Salawu, 2010). For many others, religion involves a number of gods, or deities (Omotosho, 2003; Salawu, 2010). However, some people have a religion in which no particular God or gods are worshipped. The Christian and Islamic religions, which were never an indigenous part of African heritage, are by contrast the heritage of North African Arabic and European invasions of the rest of the continent.

The Nigerian population has been growing rapidly ever since its independence in 1960. It is currently estimated to be about 167 million (The Economist, 2013, pp.49-50) and growing. As with ethnicity there is an on-going debate over the percentages of the ethnic/tribal or religious composition of the Nigerian population. This is because all the previous Nigerian headcounts or censuses have been based on guesswork (Dike, 2006; Dike, 2003). However, according to the US Department of State report of 2009, the Nigerian population is nearly 50 percent Christian and 50 percent Muslim. Elsewhere, it has been argued that the country is 50\% Muslim, 40\% percent Christian and $10 \%$ African traditional religion (Kwintessential, 2010). While Muslims dominate the North (Hausas), Christians dominate the Southeast (Igbos). However, the Western part of Nigeria that is characterised by the Yoruba ethnic nationality is not dominated by anyone particular religion (Olojo, 2014). The Yorubas adopt a combination of Christianity, Islam and African traditional religion unlike all the other ethnic nationalities in Nigeria (Omotosho, 2003). Thus, Nigeria is divided along religious lines with each group hanging on tenaciously to their own faith or belief (Dike, 2003). Religion has so dominated the people's way of life that it is difficult to distinguish what is secular in Nigeria from that which is religious. Yet, it remains a powerful source of conflict in the country (Omotosho, 2003; Salawu, 2010; Olojo, 2014). Identity conflicts are often linked with religious conflict in Nigeria. This is basically because 
most of the ethnic groups are also identified with a particular religion, resulting in most conflicts that started as ethnic conflicts, but often assuming religious undertones.

It is pertinent to note that both the Muslims and the Christians within their own organisations are equally divided among themselves. The Muslims have the Sunni and the Shia whereas the Christians have numerous subsets such as the Anglican, Catholics, Pentecostals, Methodists and Mormons among others. On many occasions, Christians not only marry Muslims and vice visa, but they also inter-marry within the ethnic subsets; these unions, however, have not reduced the ethnoreligious tensions (Salawu, 2010).

Historically, Islam was said to have been introduced to Nigeria by Usman Dan Fodio in the early $9^{\text {th }}$ century, a time characterised by trans-Saharan trade activities. Notably, these military incursions as well as (Islamic) religious conversions also took place at this time (Enukora, 2005). Islamic traditions were quickly assimilated and accepted with enthusiasm in the Northern part of Nigeria that borders the Sahara. Today, Islamic beliefs tend to be similar to the Northern Nigerian cultures.

Christianity was introduced into Southern Nigeria in the $16^{\text {th }}$ century by the Europeans who came into Nigeria in search of goods and raw materials. With the influx of the British missionaries who continued to persuade the people to accept the faith (Omorugbe and Omohan, 2005), the Southerners were converted to Christianity. This divergent faith of the Northerners and Southerners quickly resulted into conflicts with regards to religious ideas and a contest for supremacy over the country's resources.

As with so many other African countries, "the colonial power defined, classified, numbered and mapped" Nigerian ethnic/tribal groups "to create administrative units to facilitate better political and institutional control” (Porter, July 25, 2011, para4). The British method of divide and rule brought into the lime light the cultural and religious differences that promoted ethno-religious animosities within Nigerian society.

Competition for political power and resources among the ethnic groups has since remained high and has thus politically destabilised Nigerian society (Dike, 2003; Dike, 2006). Thus, the colonial administration regionalised the country, based on ethnic background and religion and concentrated power amongst the Muslim Northerners. This, as noted earlier, implanted the feeling of domination in the people thereby rendering any sense of national identity in Nigeria almost impossible, thereby complicating the nation building process.

\subsection{Incidences of Ethno-Religious Conflicts in Nigeria}

It has been noted that religious induced violence has a relationship with "faith and conviction where people of a particular faith build walls around their faith to the exclusion of others" (Danjibo, 2012, p.235; Nigeria Watch, 2011; Udeke, Okolie-Osemene, and Aghalino, 2013; Olojo, 2014). The clash of religion is not peculiar to Nigeria. In fact, most multi-religious nations have experienced different conflicts. For example, in Plateau State, some local groups reported that over 53,787 lives were lost in religious conflicts that were generated by ethnic tensions in the Middle Belt (Nigeria Watch, 2011).

Since independence in 1960, ethno-religious conflicts have littered Nigeria's landscape. The combination of ethnic and religious conflict referred to in this paper is branded as ethno-religious conflict. It is a situation where the relationship between the members of a particular ethnic group and another ethnic group in a multi-religious and multi-ethnic society is characterised by fear and suspicion leading to violence (Salawu, 2010).

The feeling of insecurity has given birth to the formation of ethnic militias such as the Oodua People Congress (OPC), the Bakassi Boys, the Egbesu Boys of Africa, and the Niger-Delta Peoples Volunteer Force (NDPVF). Others include the Igbo People's Congress (IPC), Arewa People's Congress (APC), MASSOB that is struggling for the re-establishment of the state of Biafra, and the Movement for the Survival of Ogoni People (Dike, 2006) and most recently the violent Boko Haram- the group whose name translates as "Western education is forbidden” (Time, May 19, 2014, p. 12) among many others. The emergence of these ethno-religious groups has heightened ethnic division in Nigeria with each group suspecting the other. This has affected the world of politics, policy, communications and relationships in Nigeria.

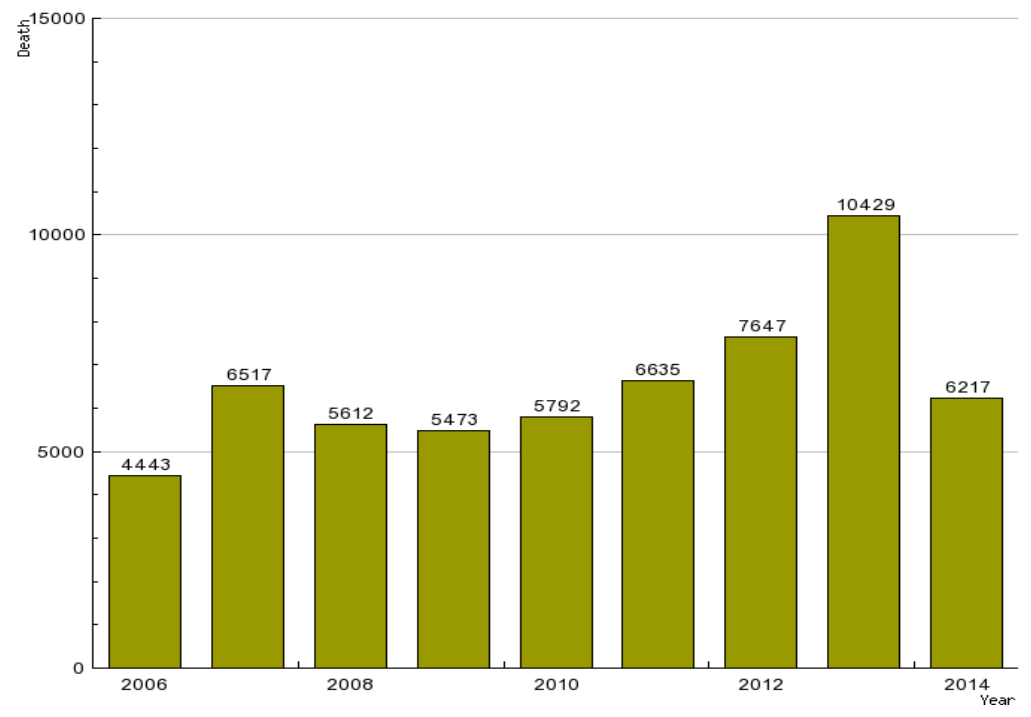

Source: culled from Nigeria Watch database by the author 
Similarly, Ethno-religious conflicts affected Southern Kaduna especially the Kasuwan Magani insurgencies between 1980/1981, the 1984 Gure/Kahagu crisis, the 1986 Lere riots, the 1987 Kafanchan riots, and the Zangon Kataf disturbances of February and May 1992 among others (Abdu Raufu Mustapha, 2003; Kazah-Toure, 2003).

The introduction of section 38 (1) and 10 into the 1999 Nigerian constitution, which grants freedom of religion, but prohibits a state religion, has given rise to a number of ethno-religious conflicts (the 1999 Nigerian Constitution). The Enugu and Kaduna riots provide remarkable examples of such conflicts, which are deeply rooted in the inclusion of the Sharia Islamic Legal Code into the document. The graph below which was culled from the Nigeria Watch database demonstrates the rate of manifestation of ethno-religious conflicts incidents in Nigeria.

The graph shows that 2013 was the most deadly year in Nigeria.

\subsection{Manifestation of Ethno-Religious Conflicts in Nigeria}

Ethno-religious conflicts have made Nigeria a turbulent enclave. The manifestation of such conflicts has been the source of deadly conflicts between different religious groups and communities. Such conflicts have manifested themselves after general elections, during religious clashes in other parts of the world and also after the killing of Christians in the north with attendant reprisal attacks in some south-eastern states just like the incidents between 1999 and 2002 in Anambra and Abia States.

The foregoing made some Nigerian scholars argue that "ethnic conflicts in Nigeria portray a nation that is enmeshed in primordial loyalties which contributed to the avoidable and senseless killing of hundreds of people after the 2011 presidential election” (Udeke, Okolie-Osemene, and Aghalino, 2013, p. 6).

The graph (on p. 12) shows that from 2002 when Boko Haram was formed "by its spiritual leader Ustaz Mohammed Yusuf” (The London Economic, May 20, 2014, para 4), violent ethno-religious conflicts have been on the increase (Time, May 19, 2014). The manifestation of these conflicts was at its peak in 2012 and 2013 when the Islamist group stormed a gathering of Igbo Christians who were shot sporadically, killing over a dozen of innocent citizens and injuring others in the apparent execution of an ultimatum given by the Boko Haram Islamist sect to Southern Christians living in the North to leave (Onuoha, 2010). The Boko Haram Islamic religious groups caused a lot of havoc in Nigeria in 2014 by bombing public and private buildings including car parks (Chothia, 2014; Olojo, 2014).Currently, the group tends to focus on young school girls, as demonstrated by the abduction of the Chibok schoolgirls numbering about 200. Another incident is when they ambushed a bus and killed students who were going to sit the Joint Admission and Matriculation Board (JAMB) examination. Both incidences took place in Borno State.

\subsection{The Social Identity Theory}

This section brings social identity theory into the discourse because ethnicity and religion is a form of identity. Any government's attempts to undermine or tamper with the identity of a group can lead its members to "fear that their culture will be extinguished" (The Economist, March $8^{\text {th }}-14^{\text {th }}, 2014$, p. 13). This often leads to social conflict, the killing of innocent citizens as well as socio-political instability. It is pertinent to note at this juncture that the killing of citizens by any group is always perceived by the international community as "monstrous and unjustifiable” (The Economist, March $8^{\text {th }}-14^{\text {th }}, 2014$, p. 13).

As a phenomenon with dynamic components, it is believed that social identity is a moderating factor influencing individual behaviour in groups and as well determines the membership of the individuals in the groups (Korte, 2007, p. 167; Hogg et al, 1995). This means that the membership of a group determines the identity of individuals to a great extent.

The Social Identity Theory by Tajfel and Turner (1985) was developed to explain the psychological basis of intergroup discrimination. It proposes that membership of social groups forms an important part of an individual's identity. They argue that people tend to classify themselves and others into various social categories; this takes the form of organizational membership, religious affiliation, gender, and age cohort. In terms of stereotyping among groups, Korte (2007, p. 170) advocates that individuals who belong to a group are assigned a prototype of characteristics that classify them and identify them with the group. Put differently the more a person is affiliated to a group the stronger his or her identity with the group will be.

The theory suggests that a person does not only have one "personal self" (Barnard, 2011) but rather several selves that correspond to widening circles of group membership. Different social contexts may trigger an individual to think, feel and act on the basis of his personal, family or national "level of self" (Turner, 1982). An individual has a number of social identities and any attempt to destroy them could result in social conflicts and anti-government activities. Accordingly, members of a group create a sense of in-group feeling; for that reason, they will support their own group at the outlay of other groups. When an individual interacts with someone else, they do not act as an individual but as a representative of a whole group or category of people.

\subsection{Key causes of Ethno-Religious Conflicts in Nigeria}

Nigeria is a country that is characterised by ethnoreligious conflicts. The political system in the country has been blamed for ethno-religious conflicts (Tijani, 2012, p. 250; Danjibo, 2012; Udeke, Okolie-Osemene, and Aghalino, 2013; Olojo, 2014). This means that the nature of governance also contributes to the unity of different groups.

According to the Nigeria Watch project (2011, p. 20) religious and ethnic clashes are notable sources of casualties between Christians and Muslims from the south and north respectively to the extent that an average of 1,090 fatalities are recorded per year, as against 410 in the events recorded by Nigeria Watch between 2006-2011. Out of most states in Nigeria, the Plateau, Kano and Kaduna states have been the hotspots of ethno-religious conflicts where adherents of Christianity and those of the 
Islamic groups have been embroiled in violent clashes that affect the political stability in the country.

Specifically, ethno-religious conflicts in Nigeria are often caused by the factors listed below, among others:

- The Nigerian government's neglect of the needs of ethnic and religious groups, victimisation, discrimination, marginalisation, bigotry, and violation of human rights, corruption and environmental degradation (Salawu, 2010, p. 348; Olojo, 2014; Okolie-Osemene, 2015).

- Poor leadership and governance that culminate in poor policies that leads to unemployment, underdevelopment and poverty. This transmogrifies Nigeria from a nation perceived by the international community as being a rich country, into having a reservoir of poor people who are easily angered and available to fight or instigate conflicts or warmongering.

- The breakdown of traditional institutions, such as the family and the lack of a high standard education (Salawu, 2010).

- The lack of effective inter-religious dialogue and insensitivity to the feeling of other groups, usually heightened by religious fanaticism, agitation for resource control, large scale inequality, poverty and youth unemployment (Adeola, 2010; Olojo, 2014; Udeke, Okolie-Osemene, and Aghalino, 2013).

- This is also the case of International allies, such as in the Middle East where the influence of Soviet socialism was replaced by Islamism (Salawu, 2010). With this new ideology many scholars argue that Islamic extremism is determined to resent the social impoverishment and excessive modernisation of the post-Cold War era (Salawu, 2010: Kibble, 2002: Horton and Hunt, 1980).

- Many incidences of terrorism have been linked to this new misplaced ideology, including the 2001 September 11 attack in the United States (Kibble, 2002).

There were times when media reports generated controversies that led to ethno-religious conflicts which climaxed in the death of hundreds of people. For instance, 12,000 Nigerians were reported dead following sectarian violence since 1999 (Nigeria Watch, 2011, p.20). The tradition of unprovoked attacks in some northern states against Christians, and reprisal attacks by both Christians and Muslims have continued to escalate avoidable interreligious conflicts which are usually fuelled by the emotional attachment of people to ethnic identity.

On the religious clashes between Muslims and Christians, Olojo (2014, p. 7) has this to say, thus: "it remains inconclusive whether or not more Muslims than Christians (or vice versa) are killed because of violence in general in Nigeria.” Many deaths have been recorded as a result if the religious violence.

\subsection{Managing the Ethno-Religious Conflicts in Nigeria}

In the management of ethno-religious conflicts in Nigeria, Albert (1993, p.19), “concrete solutions must be found for ethnic and religious conflicts in Nigeria, otherwise urban dwellers, whether indigenous or strangers will learn to take the law into their own hands"
Over the years, the Nigerian government has adopted some rhetorical measures in its efforts to manage the ethno-religious conflicts littering the country's political landscape. Some scholars have argued that the measures are not effective given the continued escalation of such conflicts in society (Dike, 2006). The 2002, 2004, and 2008 Jos upheaval (Adeola, May 2010, p.193) and the most recent and dreadful Boko Haram attacks noted above are good examples. The two measures adopted by the government of Nigeria are the coercive and the judicial methods (Omorogbe and Omohan, 2005).

The coercive method involves the deployment of troops, which in reality has only served to worsen the situation. This method has failed apparently because it involves a lot of shootings and more often than not innocent citizens are the victims. This type of conflict management strategy does not include extensive mediation; the military officers do not seem to possess the expertise required to quell conflicts. As noted earlier, the restriction of religious teaching for fear of militant Islamism will lead the Moslem communities to fear that their culture will be banned or eliminated.

Another measure adopted by the government was the use of the judicial system, which has failed because it has brought the victims more sorrow than expected relief. This method is affected by poor logistics; therefore, it takes time and often does not receive the required cooperation by the parties involved in the conflict (Omorogbe and Omohan, 2005). Following the apparent failures of the adopted strategies the next section of this article offers operational ways of managing the Nigerian experience of ethno-religious conflicts.

\section{Recommendations and Conclusion}

\subsection{The Way forward (Recommendations)}

This section suggests possible ways forward for Nigeria in the area of religious tolerance and peaceful cohabitation. The recommendations of this article on what should be done to eradicate ethno-religious conflict are precise.

One of the ways forward is to show the Moslem communities how they can live in harmony and prosper together with other ethnic and religious groups in the country. It has been noted that religious tolerance and inter-religious dialogue are among the effective options for "peaceful coexistence and progress in Nigeria" (Adeola, May 2010, p. 195). This can be possible if each group strives against ethnic and religious prejudice in Nigeria. Dialogue and proper negotiation should be adopted in the settlement of ethnic and religious conflicts. Ndubisi (1991, p. 182) maintained that "Nigeria's elderly political leaders have a very strong role to play in converting the Nigerian garden from a zoological to a paradisiac one". This is based on the fact that ethnoreligious conflicts create instability in which elder statesmen can also have the capacity to create peaceful society. Given that most ethno-religious conflicts are planned, executed and escalated by men, there is a need for peace advocates to target volatile areas to transform this ugly trend. Youths should avoid the temptation of adopting confrontation or reprisal strategies which 
unfortunately escalate ethnic disputes. This makes it crucial for us to identify that the aim of religion is not to divide the people, but to offer groups freedom of worship and choice of identity to serve a deity.

However, since poverty has been noted as among the instigators of social conflict, economic development needs to be directed to the communities to empower the people. Otherwise, the politicians will continue to employ the poor (unemployed) youths as their touts to silence their real or perceived political enemies, thereby causing havoc and political instability and in society as a whole.

Proper religious teaching and education should be given to every participant in the religious groups in society and they should be made to understand that ethnicity and religion should not be used as weapons of hate and the destruction of life and property. This will likely bring a restraining influence on religious fanatics and thus tame conflicts and violence within society.

The Vice Chancellor of the University of Ilorin, Isahaq Oloyede, asked as he lamented the wanton destruction of lives and property in Jos: "If all religions teach love and Nigerians were found not quite long ago to be [one of] the most religious people in the world, it is high time we asked ourselves if we are living our religions. [Or] Is our religion living in us?” (See Folola, F. in the Punch Newspaper, December 27, 2008). The use of traditional institutions and religious leaders as peace-makers with the adoption of a strategy of openness and sincerity is the key to peaceful ethno-religious co-habitation and national prosperity.

Succinctly, this article, therefore, suggests the following as a possible more effective way of managing the conflicts:

- More commitments from all levels of government (local, state and federal government) with each level establishing its own conflict prevention/resolution strategy, including the presence of sufficient security. This would rather tame social conflicts and upheavals.

- The government can also empower the religious and traditional leaders to improve inter-ethnic and religious communication, peace and harmony among their subjects.

- The use of civil society organisations and NGOs could be another effective tool.

- The government should strengthen peace building associations/organisations, such as the Public Complaint Bureau, the National Orientation Agency (NOC) and the National Youth Service Corps (NYSC) program. In particular, the purpose of the NYSC program is among other things for the "encouragement and development of common ties among the youths of Nigeria and the promotion of national unity” (See Decree NO. 24 of May 1973).

\subsection{Concluding Remarks}

Ethno-religious conflicts have created an atmosphere of negative peace in Nigeria. That is why this article adopts the assertion that 'Nigerians were one of the most governable, tolerant and patient people in the world, to the extent that the generality of our people recognised and appreciated honesty, earnestness, justice, equity and fairness (Ndubisi, 1991, p. 111). No doubt, it is intolerance that causes groups to become engulfed in crises. Religious identity is not evil, but the way people use it to relate with others can be used to serve evil means. Using religion to demonise society breeds deadly violence.

This article has explored the nature and key causes of the conflicts between different religious and ethnic groups in Nigerian society. The resurgence of ethnic conflicts gave birth to ethnic militias in Nigeria with different security implications considering the military attributes of the groups and individuals involved.

Apart from colonial experience, other causes of the conflicts include corruption, domination, and marginalisation, the breakdown of traditional institutions, victimisation and the use of military troops by the Nigerian government in managing the conflict. This is considered a failure on the part of the Nigerian government. The eradication of the ugly trend is not an impossible task. Practically, good governance is the main antidote to the unending ethno-religious conflicts in the country. The government and other stakeholders including civil society in Nigeria should make provision for sufficient funds to procure modern gadgets and train enough security personnel to tame the occurrence of ethno-religious crises in civil society. The provision of job-skill training and employment to the teeming poorly educated and unskilled youths would go a long way to reducing the level of poverty and conflicts in the Nigerian society. Unfortunately, over 50 percent of Nigerian youths particularly in the Northern part of the country are unemployed and are easily attracted to the extremist groups such as Boko Haram. Otherwise, managing the Nigerian experience of ethno-religious crisis will remain a daunting task.

\section{References}

[1] Abdu, H and Umar, L. (2002). Ethnic and Religious Crisis in Kaduna. in Hope Betrayed? : A Report on Impunity and StateSponsored Violence in Nigeria. Geneva/Lagos: OMCT/CLEEN.

[2] Adeola, A.A. (2010). "Religious Tolerance and Dialogue: Conditionality's for Peaceful Co-existence and Progress in Nigeria."International Journal on Social Science Research and National Development, 1 (1), 189-199.

[3] Albert, 1.O. (1999).Community Conflict in Nigeria: Management, Resolution and Transformation. Ibadan: Spectrum.

[4] Albert, I. O. (1993) Inter-ethnic relations in a Nigerian city: a historical perspective of the Hausa-Igbo conflicts in Kano, 19531991. Ibadan, IFRA-Nigeria.

[5] Taheri, A., (1987).Holy Terror. London: Hutchinson, p. 20.

[6] Bodansky, Y., (1999).Bin Laden: The Man Who Declared War on America. Rocklin, CA: Forum Publishing, pp. 226-27.

[7] Chothia, F. (2014). "Who are Nigeria's Boko Haram Islamists?”. $B B C \quad$ News-Africa, May 20; also see http://www.bbc.com/news/world-africa-13809501-accessed May 23, 2014.

[8] Daley, P. (2006). 'Ethnicity and political violence in Africa: The challenge to the Burundi state'. Political Geography 25 (2006), 657-679.

[9] Danjibo, N. D. (2012). The Impact of Shari'a on Inter-Group Relations in Post-Colonial Nigeria. In Ogbogbo, C. B. N., Olaniyi, R. O. and Muojama, O. G. Eds. The Dynamics of Intergroup Relations in Nigeria Since 1960. Ibadan: BWright Integrated Publishers. Pp. 231-249.

[10] Dike, V.E. (2003). Nigeria and the Politics of Unreason: A Study of the Obasanjo Regime. London: Adonis and Abbey Publishers, Ltd.

[11] Dike, V.E. (2006). Democracy and Political Life in Nigeria (second edition). New York, iUniverse, Inc. 
[12] Enukora, L.O. (2005). “Managing Ethno-Religious Violence and Area Differentiation in Kaduna Metropolis”, in A.M. Yakubu et al (editors), Crisis and Conflict Management in Nigeriasince 1980. (2), P. 633. Baraka Press and Publishers Ltd., Kaduna, Nigeria.

[13] Hogg, M. A., Terry, D. J. and White, K. M. (1995), A Tale of Two Theories: A Critical Comparison of Identity Theory with Social Identity Theory. Social Psychology Quarterly 58 (4): 255-269.

[14] Horton, P. B. and Hunt, C. I. (1980). The Sociology of Tokyo. Mac-Graw Hillham: Kogakwsha hall Press.

[15] Irobi, E.G., (2005). "Ethnic Conflict Management in Africa: A comparative Case Study of Nigeria and South Africa”. Accessed May 21, 2014 from http://www.beyondintractability.org/class_studies/nigeria_southafrica.jsp?nid=6720.

[16] Juergensmeyer, M. (2000). Terror in the mind of God: The global rise of religious violence, Berkeley: University of California Press.

[17] Kazah-Toure, T. (2003). Ethno-Religious Conflict in Kaduna State. Kaduna: Human Rights Monitor.

[18] Kibble, D. G., (2002). "The Attack of 9/11: Evidence of a Clash of Religions?” In Parameters-autumn, US Army College (32), Part 3, p. 34-45, ISSN 0031-1723; also available http://strategicstudiesinstitute.army.mil/pubs/parameters/articles/0 2autumn/kibble.pdf; accessed June 1, 2014

[19] Korte, Russel F. (2007). A Review of Social Identity Theory with implications for Training and Development. Journal of European Industrial Training 31 (3): 166-180.

[20] Maregere, T. P. (2011). 'Religion: A source of conflict and a resource for peace'. Conflict Trends (1) 17-23

[21] Mc Bride, J. (2002). Religion in Conflict. Available at http://www.abcog.org/nh/conflict.htm; accessed 12 May 2014.

[22] Ndubisi, Acha F. (1991). Nigeria What Hope? Enugu: CECTA (Nig) Ltd.

[23] Nigeria Watch (2011). Third Report on Violence (2006-2011). June http://www.nigeriawatch.org/media/html/NGA-WatchReport11(1).pdf accessed 20 January, 2015.

[24] Okolie-Osemene, James. (2015). Oil companies and lethal violence in Nigeria: Patterns, mapping, and evolution (2006-2014). IFRA-Nigeria working papers series, $n^{\circ} 44$ : Pp. 1-28. http://www.ifra-nigeria.org/IMG/pdf/oil-companies-violencenigeria.pdf

[25] Okumagba, Paul. 2009. Ethnic Militias and Criminality in the Niger-Delta. African Research Review 3 (3): 315-330.

[26] Olojo, E. A. (2014). Muslims, Christians and religious violence in Nigeria: patterns and mapping (June 2006-May 2014). IFRANigeria working papers series, $\mathrm{n}^{\circ} 33$ : Pp. 1-44. http://www.ifranigeria.org/IMG/pdf/muslims-christians-religious-violencenigeria.pdf

[27] Omotosho, A. O. (2003) 'Religious violence in Nigeria-the causes and solutions: An Islamic perspective’. Swedish Missinlogical Theme 15-31.

[28] Omorogbe, S. K. and Omohan, M. E. (2005). 'Causes and Management of Ethno-Religious Conflicts: The Nigerian’ in A. M. Yakubu, et al. (editors). Crisis and Conflict Management in Nigeria Since 1980 (2), 557 Kaduna, Nigeria: Baraka Press and Publishers Ltd;
[29] Onuoha, F. C. (2010). "The state and management of religious violence in Nigeria: A case of the July 2009 Boko Haram revolt.” Ph.D. Seminar paper presented to the department of political science, University of Nigeria, Nsukka, Nigeria.

[30] Porter, S., (2011, July 25). "Ethnicity in Africa: a road to conflict or a path to peace?” African Faith \& Justice Network, Washington, D.C; www.afjn.org, access May 22, 2014.

[31] Salawu, B. (2010) 'Ethno-religious conflicts in Nigeria: Causal analysis and proposals for new management strategies'. European Journal of Social Sciences 13 (3), 345-353.

[32] Samuel P. H., (1993) "The Clash of Civilizations,” Foreign Affairs 72, 22-49.

[33] Shepard, J., M. (1981).Sociology of Africa. New York: West Publishing Co.

[34] Thompson, A. (2007). An Introduction to African Politics $2^{\text {nd }}$ ed.( London and New York; Rout ledge.

[35] Time (2014). See "Plight of Nigeria’s Missing Girls Sparks Global Outrage”, May 19, p. 12.

[36] The Constitution of the Federal Republic of Nigeria-1999

[37] The Economist (2013). see Nigeria "Lurching ahead”, April $13^{\text {th }}$ $19^{\text {th }}$, p. 49.

[38] The London Economic (2014). See Boko Haram-A history. Accessed May 2 3, 2014, from http://www.thelondoneconomic.com/2014/05/20/boko-haram-ahistory/

[39] The Punch Newspaper (2008). See F. Folola "Why political, religious crisis persist in Nigeria,” December 27, p. 17

[40] Tibi, B., (2001).Islam Between Culture and politics. Basingstoke, England: Palgrave, p. 216

[41] Tijani, Abdulwahab. (2012). Intergroup Influence and Conflicts in Yoruba Muslim Family. In Ogbogbo, C. B. N., Olaniyi, R. O. and Muojama, O. G. Eds. The Dynamics of Intergroup Relations in Nigeria Since 1960. Ibadan: BWright Integrated Publishers. Pp. 250-260.

[42] Turner, J. C., (1982). "Towards a cognitive redefinition of the social group.” In H. Tajfel (edited), Social Identity and Intergroup Relations. Cambridge: Cambridge University Press.

[43] Udeke, Udechukwu, Okolie-Osemene, James and Aghalino, Samuel O. (2013). "Complexities and Dynamics of EthnoReligious and Identity-based Conflicts in Nigeria." A38 Journal of International Law 2 (1): Pp. 201-211. https://docs.google.com/a/athirtyeight.com/viewer?a=v\&pid=sites \&srcid=YXRoaXJ0eWVpZ2h0LmNvbXx2b2x1bWUtMnxneDpl YTlmY2M1MTZjODg1OA

[44] Wooldrige, M., (2004). “Can religion be blamed for war?”BBC News, $24 \quad$ February 2004 http://news.bbc.co.uk/2/hi/programmes/wtwtgod/3513709.stm; accessed 12 May, 2014.

[45] Kwintessential (2010). "Nigeria, Language, Culture, Customs and Etiquette,” May $30^{\text {th }}$ M available at http://www.kwintessential.co.uk/resources/globaletiquette/nigeria.html; accessed on May 20, 2014. 